\title{
The Impact of Corporate Governance on the Efficiency Performance of the Thai Non-Life Insurance Industry
}

\author{
Wen-Yen $\mathrm{Hsu}^{\mathrm{a}}$ and Pongpitch Petchsakulwong ${ }^{\mathrm{b}}$ \\ ${ }^{a}$ Department of Risk Management and Insurance, Feng Chia University, Taichung, Taiwan. \\ E-mail: wyhsu@fcu.edu.tw \\ ${ }^{\mathrm{b}} \mathrm{PhD}$ Program in Business, Feng Chia University, Taichung, Taiwan. \\ E-mail: p_pongpitch@hotmail.com
}

This paper examines the relation between corporate governance and efficiency performance of public non-life insurance companies in Thailand over the period 2000-2007. Data envelopment analysis is used to compute an insurer's efficiency performance including technical, allocative, cost, and revenue efficiency. We then employ truncated bootstrapped regression to test the relation between efficiency performance and corporate governance. The results show that the characteristics of corporate governance influence the efficiency performance of non-life insurers. In particular, board independence, diligence, and firm size have a positive impact on the efficiency performance of the Thai non-life insurance companies. However, audit committee size, diligence, divergence between voting rights and cash flow rights, board tenure, board age, as well as board ownership have a negative impact on the efficiency performance. Finally, our empirical evidence also indicates that there is an unclear relation between an insurer's efficiency performance and the board size, the proportion of financial expertise on an audit committee, and the board compensation. The Geneva Papers (2010) 35, S28-S49. doi:10.1057/gpp.2010.30;

published online 29 September 2010

Keywords: data envelopment analysis; corporate governance; efficiency performance; Thai non-life insurance

\section{Introduction}

More than a decade ago, the Asian Financial Crisis erupted in Thailand, devaluing the baht under massive speculative pressure, dropping the Thai economy into a financial gulf, and bankrupting many financial institutions. ${ }^{1}$ The Thai government wanted to know the causes of this crisis and find ways to prevent it for the future. This search led to the creation of a new structure for good corporate governance and oversight of management. Then, the government initiated and promoted the concept of good

\footnotetext{
${ }^{1}$ For more examples of corporate governance failure in Thai companies, see Viverito (1998), Nikomborirak and Tangkitvanich (1999), and Leightner (2007). In addition, Johnson et al. (2000) find that, in the case of the Asian Crisis in 1997-98, the worse economy effects to more expropriation by manager and thus a larger fall in asset prices in the countries with weakness of corporate governance. They suggest that, in crisis situations, corporate governance should be used first in determining the extent of macroeconomic problems.
} 
corporate governance ${ }^{2}$ to deepen and broaden this concept among the listed companies, financial intermediaries, and regulators.

Specifically, all listed companies in Thailand have to follow the Public Limited Company Act B.E. $2535^{3}$ as well as the Securities and Exchange Commission (SEC) regulations in order to implement good corporate governance. Some essential characteristics of the board of directors and audit committees are required. First, the board of directors shall comprise at least five members, of which no fewer than three members will be independent. For larger boards, at least one third must be independent. All directors shall have a variety of expertise and experience suitable for the company's business and monitoring. Second, the board shall meet at least four times a year, depending on the issues at hand. Third, although the audit committee size depends on the volume, scope of responsibilities, and efficiency in the performance of work, an audit committee shall have at least three members. In addition, all members have to be independent and at least one member shall have experience or knowledge of accounting or finance. Something worth noting is the requirement that audit committee members cannot hold shares of over five per cent of the paid-up capital of a company, nor can they be affiliated, associated, or related to anyone within said company, including shares held by such persons. Finally, regarding the frequency of the audit committee meetings: they shall be held at least four times a year, depending on the size of the business and the delegated duties.

Along with adhering to the Public Limited Company Act and SEC regulations, insurance companies must also adhere to the Office of Insurance Commission (OIC) regulations, which have its own rules for corporate governance. For example, the board of directors shall have at least seven members, of which at least one fourth shall be independent. All board members shall have an educational background and work experience applicable to the company's business and monitoring needs. Also, each audit committee shall be composed of at least three non-executive members and not less than two independent directors.

Although the Thai government has spent a lot of effort on improving corporate governance, only a few studies examine the impact of this new corporate governance structure. Connelly and Limpaphayom ${ }^{4}$ study the relation between a board's characteristics and performance on the life insurance companies in Thailand. They find that the board's composition effectively reduces acquisition costs and has a significantly positive relation to profitability. However, board size has no relation to performance for life insurers. In a study of local commercial banks in Thailand, Pathan et al. ${ }^{5}$ provide similar results that board independence is positively related to performance, but conversely, board size is negatively related to performance. These two papers consider only a few characteristics of a board, that is, board size and independence, ignoring the fact that board meeting frequency and the characteristics of the audit committee could also affect a firm's performance. On the other hand, since

\footnotetext{
${ }^{2}$ In some countries, there exists a distinction between good corporate governance and corporate governance, but in this paper, the two terms are equal.

3 B.E. stands for Buddhist Era, Thailand year.

${ }^{4}$ For example, Connelly and Limpaphayom (2004).

${ }^{5}$ Pathan et al. (2007).
} 
the Thai government has spent a lot of effort in promoting good corporate governance and set regulations for board/audit committee characteristics, using only a few of those characteristics of the board is not adequate in examining the impact of good corporate governance enacted by the Thai government on a firm's performance.

The purpose of this paper is to investigate the relation between a more complete set of corporate governance variables and efficiency performance of non-life insurance companies in Thailand via the panel data covering the period 2000-07. We employ data envelopment analysis (DEA) to compute the efficiency performance of insurers (technical, allocative, cost, and revenue efficiency) and then use truncated bootstrapped regression to test the relation between efficiency performance and corporate governance.

The empirical results show that the characteristics of corporate governance influence the efficiency performance of Thai non-life insurers. In particular, board independence, board meeting frequency, and firm size have a positive impact on efficiency performance. On the contrary, audit committee size, audit committee meeting frequency, divergence between voting rights and cash flow rights, board tenure, board age, and board ownership have a negative impact. Our results also show an unclear relation between an insurer's efficiency performance and the board size, the proportion of financial experts on an audit committee, and the board compensation.

This study adds to the literature in three aspects. First, this paper is only one of a few studies on this subject that specifically utilises the Thai non-life insurance companies' data in order to investigate the relation between corporate governance and efficiency performance. This investigation is important since poor corporate governance caused the financial crisis in Thailand. ${ }^{6,7}$ Further, it is necessary to examine whether a firm's governance structure improves its efficiency, after the effort the Thailand government has spent in promoting good corporate governance. Second, instead of examining the impact of board size and board independence on performance, as Connelly and Limpaphayom ${ }^{4}$ and Pathan et al. ${ }^{5}$ we investigate the impact of a more complete set of board/audit committee characteristics on an insurer's efficiency performance. Since the lack of good monitoring on management was one of the pitfalls of the financial crisis, investigating the relation between efficiency and the characteristics of board/audit committees allows us to examine the overall effectiveness of its monitoring. Third, in addition to the use of technical, allocative, and cost efficiency scores to measure the efficiency performance of a company, this paper adds the revenue efficiency score. The revenue efficiency is important because firms with poor corporate governance may have a higher agency cost and, consequently, could be penalised by the market in terms of lower revenue. If the introduction of good corporate governance means a reduction of an agency cost, and represents a legitimate response to the insurance market, then insurers with good corporate governance could potentially be rewarded with higher revenue. If, on the contrary, the introduction of good corporate governance by an insurer is simply an attempt to meet the regulatory requirements, then it will not be appreciated by the market and there will be no benefit.

\footnotetext{
${ }^{6}$ Viverito (1998).

7 Johnson et al. (2000).
} 
This paper is organised as follows: The next section develops the hypotheses. The following section describes the data and methodology. The penultimate section presents and discusses empirical results. The final section concludes.

\section{Hypothesis development}

Corporate governance mechanism is an important method for companies to minimise agency cost and help improve performance. Papers use various proxies to measure performance, such as return on assets, ${ }^{4}$ return on equity, ${ }^{8}$ and Tobin's Q, ${ }^{9}$ and study the relation between corporate governance and a firm's performance. In this paper we employ efficiency scores, calculated by the DEA, to measure a firm's performance. We use technical, allocative, cost, and revenue efficiency scores, and expect that good corporate governance will improve its efficiency performance. We review relevant literature and develop our hypotheses in this section.

\section{Board size}

The board of directors, as shareholders' representative, plays an important role in deciding the policy and strategy of a company. It must review the performance of all management teams in order to ensure that management follows company policies and strategies to maximise the benefits of its shareholders. To ensure that the board can properly fulfil its duties, the board members need to commit considerable resources and provide a variety of skills. It follows that a larger board size should be beneficial to the efficiency performance of a firm, because more members on the board would mean more knowledge backgrounds and varied opinions available to a firm, ${ }^{10}$ as well as having stricter monitoring to ensure the reduction of financial fraud. ${ }^{11}$

However, the benefits of having a larger board size might be outweighed by its costs, since an oversized board may make it more difficult to reach a consensus, suggesting that a smaller number of directors on the board could reduce coordination problems and improve its efficiency performance. ${ }^{12}$ In addition, having a larger board size may inadvertently create a free-rider problem or lead to low motivation among board members. ${ }^{13,14}$

Many studies have examined the relation between board size and the performance of a firm, and have found inconsistent results. For example, board size is positively related to profitability, ${ }^{15,16}$ and firm efficiency. ${ }^{10,17}$ On the other hand, Conyon and

\footnotetext{
${ }^{8}$ For example, Cummins and Nini (2002).

${ }^{9}$ Agrawal and Knoeber (1996).

${ }^{10}$ Huang et al. (2008a).

${ }^{11}$ Beasley (1996).

12 Jensen (1993).

${ }^{13}$ Herold (1979).

14 Yermack (1996).

15 Dowen (1995).

${ }^{16}$ Dalton et al. (1999).

${ }^{17}$ Hardwick et al. (2004).
} 
$\mathrm{S} 32$

Peck, ${ }^{18}$ as well as Pathan et al. ${ }^{5}$ have found evidence suggesting that a board size is negatively related to return on equity. On the basis of these inconsistent results, increasing board size may not necessarily improve efficiency performance. Therefore, we propose the following hypothesis:

H1: There is no relation between board size and a firm's efficiency performance.

\section{Board independence}

A corporate board is generally composed of both inside and outside (independent) directors. The independent directors are used as a proxy of board independence and are an important factor in measuring the effectiveness of board monitoring for two reasons. First, the independent directors on the board are able to work freely and are not subject to control or influence from major shareholders, management, or other relevant parties. Therefore, they are more likely to question and monitor management to prevent fraud, because they have no economic or psychological connection with management. Second, Fama and Jensen ${ }^{19}$ suggest that independent directors have more motivation to build-up and improve their reputations by providing effective monitoring. It follows that independent directors are associated with better performance, and more independent directors on a board should mean more efficiency in monitoring management, and thus reduce the opportunity for fraud in accounting and financial statements. ${ }^{11}$

In a study of the Thai life insurance industry, Connelly and Limpaphayom ${ }^{4}$ find that board independence is positively correlated with an insurer's profitability and negatively correlated with an insurer's commission expenditure. Pathan et al. ${ }^{5}$ use the Thai banks as sample and find that board independence is associated with higher profitability.

On the contrary, other studies have also found that board independence is negatively correlated with Tobin's $Q^{9}$ and efficiency. ${ }^{17}$ Huang et al. ${ }^{20}$ provide a possible explanation for the results, in that those independent directors who are excessively prudent and risk-averse may monitor management excessively, resulting in an inefficient business decision-making process. Collectively, we formulate the hypothesis as follows:

H2: There is no relation between board independence and a firm's efficiency performance.

\section{Board diligence}

The effectiveness of a board also depends on its diligence. However, since board diligence is not directly observable, board meeting frequency is often used as a proxy for board diligence. Board meeting frequency can improve efficiency performance of

\footnotetext{
${ }^{18}$ Conyon and Peck (1998).

${ }^{19}$ Fama and Jensen (1983).

${ }^{20}$ Huang et al. (2008b).
} 
a firm, since the board has more opportunities to monitor and review management's performance. Vafeas ${ }^{21}$ suggests that board meeting frequency is an important activity, because increasing the level of a board meeting frequency can help the firm to improve poor operating performance, indicating a positive correlation between a firm's performance and board diligence. Evans et $a .^{22}$ find that when a firm's performance declines, the board of directors increases its meeting frequency to try to solve the problems of declining performance. However, Rebeiz and Salameh ${ }^{23}$ argue that the frequency of a board meeting is less important to its quality. Specifically, a large number of meetings in a year suggests that the board is inappropriately playing an operating role instead of an oversight role, given that the function of the board is not to manage the firm, but rather to govern its management. Their empirical evidence suggests that there is no relation between the board meeting frequency and a firm's performance. Thus, we suggest the following hypothesis:

H3: There is no relation between board meeting frequency and a firm's efficiency performance.

\section{Audit committee size}

Like the argument posited on board size, a larger audit committee size provides stricter monitoring, but also makes it more difficult to reach conclusions. The empirical evidence regarding the relation between an audit committee size and a firm's performance is mixed. For example, Klein ${ }^{24}$ finds that an audit committee size is positively correlated with more extensive monitoring. However, other studies find no relation between an audit committee size and efficiency, ${ }^{17}$ profitability, ${ }^{25}$ and incidences of restatement of financial reports. ${ }^{26}$ The mixed empirical evidence leads to the following hypothesis:

H4: There is no relation between audit committee size and a firm's efficiency performance.

\section{Audit committee diligence}

Kalbers and Fogarty ${ }^{27}$ suggest that audit committee diligence is associated with its effectiveness. However, audit committee diligence is not directly observable. Menon and Williams ${ }^{28}$ argue that meeting frequency is a signal of diligence, and therefore, we

\footnotetext{
${ }^{21}$ Vafeas (1999).

${ }^{22}$ Evans et al. (2002).

${ }^{23}$ Rebeiz and Salameh (2006).

${ }^{24}$ Klein (2002).

${ }^{25}$ Kajola (2008).

${ }^{26}$ Agrawal and Chadha (2005).

${ }^{27}$ Kalbers and Fogarty (1993).

${ }^{28}$ Menon and Williams (1994).
} 
use an audit committee meeting frequency as a proxy for diligence. Prior research ${ }^{29}$ suggests that an audit committee that meets frequently can improve the financial accounting processes and lead to better performance. Yet, on the contrary, Rebeiz and Salameh $^{23}$ argue that the quality of meetings is also important and that increasing the number of meetings doesn't necessarily enhance a firm's performance. A survey conducted by $\mathrm{KPMG}^{30}$ suggested that audit committees feel that their effectiveness may be hampered, or negatively impacted, by overloaded agendas and activities on compliance. Empirical evidence from Huang et al. ${ }^{20}$ suggests that there exists no relation between an audit committee meeting frequency and the efficiency performance of a firm. Collectively, we suggest the following hypothesis:

H5: There is no relation between audit committee meeting frequency and a firm's efficiency performance.

\section{Financial expertise on an audit committee}

Financial experts are to place at least one member on an audit committee, as ordered by the Public Limited Company Act in Thailand. Financial expertise helps the board by preventing financial reporting problems and clarifying accounting irregularities. The results in Anderson et al. $^{31}$ suggest that the financial accounting process can be improved by having some financial expertise on the audit committee. In addition, financial expertise enables the audit committee to rely less on management, thereby becoming more independent, when evaluating management's performance. Kalbers and Fogarty ${ }^{27}$ find that having financial expertise improves the effectiveness of an audit committee.

Yet Agrawal and Chadha ${ }^{26}$ point out, on the contrary, that it is not clear whether having members with expertise on audit committee increases the effectiveness of monitoring capabilities. In addition, the inclusion of members with financial expertise on an audit committee may lead other members to be less watchful. Collectively, the hypothesis is stated as follows:

H6: There is no relation between the proportion of financial experts on an audit committee and a firm's efficiency performance.

\section{Data and methodology}

In this section we discuss the corporate governance data of the listed non-life insurance companies in Thailand. We then define the variables used in the DEA methodology to estimate their efficiency scores. These variables include quantities and prices for inputs

\footnotetext{
${ }^{29}$ For example, Abbott et al. (2003).

${ }^{30}$ KPMG (2008).

${ }^{31}$ Anderson et al. (2004).
} 
and outputs. Finally, we discuss the methodology used in analysing the relation between efficiency scores and corporate governance variables.

\section{Data}

Since corporate governance variables are only available to public firms, we utilise the public Thai non-life insurance companies as our sample and obtained our data from the Annual Registration Statement (Form 56-1) from the 2000 to 2007 period. We collect all 18 public insurer data and exclude one professional reinsurer. Also, two companies were removed due to merger and acquisition, reducing our sample size to 138 firm-years.

\section{DEA variables}

DEA is a non-parametric programming approach to calculate efficiency scores on the condition of the best-practice production function. Production function gives us efficiency score of one on production frontier. A less than one to zero score is not on the production frontier and suggests inefficiency. To calculate efficiency scores, we define input and output quantities and prices as follows.

\section{Input quantities and prices}

We follow the Cummins and $\mathrm{Nini}^{8}$ methodology in identifying three input variables: labour, equity capital, and materials and business services. The quantity of labour is the sum of the quantity of administrative and agent labours. The price of labour is a weighted average of the price of administrative and agent labours, with weights equal to expenditures on each category of labour divided by total expenditures of labour. The price of administrative labour is expenditures (salary and welfare) divided by the quantity of administrative labour. The quantity of agent labour is expenditures divided by the price of agent labour. The price of agent labour is total expenditures (commissions and brokerages) divided by total quantity of agent labour. We received the quantity of administrative labour of an insurer, total quantity of agent labour, and total commissions and brokerages in each year from the OIC, Thailand. The price of administrative labour (salary and welfare) and agent labour (commissions and brokerages) of an insurer are obtained from the Annual Registration Statements (Form 56-1).

The amount of equity capital is obtained from the Annual Registration Statements (Form 56-1). Following Cummins and Nini, ${ }^{8}$ we assume that the cost of equity capital is the sum of risk-free rate and the product of beta and market risk premium, and is constant for all insurers for a given year. Risk-free rate is defined as three months Thailand Treasury bill rate of return at the end of the preceding year. The beta is derived from a simple regression between the rate of return on the insurance industry price index and the market rate of return. The expense of equity capital is the product of a firm's capital and cost of capital. Finally, the quantity of materials and business services is equal to total expenditures minus labour costs, and then divided by its price. The price of materials and business services is the rate of change on the consumer price index (CPI). 
Output quantities and prices

Following Cummins and Weiss, ${ }^{32}$ we use a value-added approach in identifying insurer outputs. The principal outputs for non-life insurers are risk-pooling and riskbearing, real financial services relating to insured losses, and financial intermediation. However, Cummins and $\mathrm{Nini}^{8}$ argue that because total losses are highly correlated with the amount of claims settlement and risk management services, the value of real losses incurred, that is losses incurred divided by CPI, should be a good proxy of riskpooling and risk-bearing, as well as real financial services. Therefore, the output variables of insurance compose of two variables: losses incurred and intermediation.

The price of losses incurred is defined as earned premiums, minus losses incurred, and then divided by losses incurred. We then define the quantity of intermediation output as invested assets, divided by CPI, and the price of intermediation is assumed to be the rate of return on the invested assets of each insurer. Revenues of losses incurred and intermediation are the products of associated quantity and price. The DEA variables are summarised in Table 1 .

\section{Variable definitions}

The corporate governance variables employed to investigate the relation with efficiency scores are defined as follows.

\section{Dependent variables}

Efficiency scores are calculated from the DEA as a proxy for efficiency performance of firms. These efficiency scores include technical, allocative, cost, and revenue efficiency.

\section{Board of director variables}

We use three measures: board size, board independence, and board diligence to proxy for a board of director's effectiveness. We follow Klein ${ }^{23}$ and define board size (lnBDsize) as the natural logarithm of the number of directors on the board. A preliminary regression model using the proportion of independent directors on the board generates mixed results. Since the board's decisions depend on a majority of directors' opinions, independent directors may not facilitate their function if they do not dominate on the board. Therefore, we follow Klein ${ }^{23}$ and define board independence ( $\mathrm{dBDind}$ ) as one, if the board is dominated (50 per cent or more) by its independent directors, and zero otherwise. Finally, board meeting frequency (lnBDmeet) is used to proxy for board diligence, and is defined as the natural logarithm of the number of board meetings.

\footnotetext{
${ }^{32}$ Cummins and Weiss (2000).
} 
Table 1 DEA variables calculation

\begin{tabular}{|c|c|}
\hline Variables & Definition \\
\hline \multicolumn{2}{|l|}{ Input variables } \\
\hline \multicolumn{2}{|l|}{ Input quantity: } \\
\hline Administrative and agent labours & Sum of quantity of administrative and agent labours \\
\hline Equity capital & Firm's equity capital \\
\hline Materials and business services & (Total expenditures - Labour cost)/Consumer price index \\
\hline \multicolumn{2}{|l|}{ Input price: } \\
\hline Administrative and agent labours & $\begin{array}{l}\text { Weighted average of the price of administrative and agent } \\
\text { labours }\end{array}$ \\
\hline Equity capital & $\begin{array}{l}\text { Sum of risk-free rate and the product of beta and market } \\
\text { risk premium }\end{array}$ \\
\hline Materials and business services & Rate of change on the consumer price index \\
\hline \multicolumn{2}{|l|}{ Output variables } \\
\hline \multicolumn{2}{|l|}{ Output quantity: } \\
\hline Losses incurred & Losses incurred/Consumer price index \\
\hline Intermediation & Invested assets/Consumer price index \\
\hline \multicolumn{2}{|l|}{ Output price: } \\
\hline Price of losses incurred & (Earned premiums - Losses incurred)/Losses incurred \\
\hline Price of intermediation & Net profit (loss)/invested assets \\
\hline
\end{tabular}

\section{Audit committee variables}

We use audit committee size, audit committee diligence, and financial expertise on the audit committee in order to proxy for audit committee effectiveness. Audit committee size (lnADsize) is defined as the natural logarithm of the number of audit committee members. Audit committee meeting frequency (lnADmeet) is used to proxy for audit committee diligence and is defined as the natural logarithm of the number of audit committee meetings. The proportion of financial experts on the audit committee (PADexpert) is also included in the model. Following Thai SEC regulations, we define a financial expert as an audit committee member who received a degree of, or had working experience in, accounting or finance.

\section{Firm-specific control variables}

We also incorporate a number of control variables in the regression model, including the divergence between voting rights and cash flow rights, board tenure, board age, board ownership, board compensation, and firm size. Large divergence generally increases controlling shareholders' incentive as well as ability to expropriate wealth from the firm, representing a major corporate governance risk. Claessens et $a l .{ }^{33}$ find that a large divergence between voting rights and cash flow rights reduces a firm's

\footnotetext{
${ }^{33}$ Claessens et al. (2002).
} 
value. Wang et $a l .{ }^{34}$ find that the divergence negatively impacts a firm's efficiency. Therefore, following Wang et al., ${ }^{33}$ we define divergence as the difference between voting rights (per cent) and cash flow rights (per cent) of the controlling shareholder of the firm, and expect divergence is negatively related to a firm's efficiency.

Board tenure (lnTenure) is defined as the natural logarithm of the average number of years the director has served on the board. Board tenure is not limited; however, Huang et al. ${ }^{10}$ suggest that directors should receive more knowledge and experience in the business area if they serve longer time within the same company. To its detriment, the higher the average tenure of directors on the board might be, the more harmful it would be to the efficiency performance of a firm, because familiarity between the board members and the managers may prevent them from effectively monitoring those managers. Bacon and Brown ${ }^{35}$ argue that a director's long standing on the board, or having a relationship with its managers, may be familiar with or trust in those managers. The disadvantages from too much familiarity between these two parties will happen when the directors are too lax about a manager's operations, resulting from too much reliance on the managers' judgement. Therefore, we conclude that there is no relation between board tenure and a firm's efficiency performance.

We include board age (lnBDage), defined as the natural logarithm of the average age of directors on the board, as a control variable. The higher average age of directors should be beneficial to a firm's performance, because they would have more knowledge and experience in doing business. However, the contrary could be just as true; senior directors may respond to their duties slower than younger directors, possibly because of declining health associated with a higher age, leading to poor performance. Collectively, we hypothesise that there is no relation between board age and a firm's efficiency.

The proportion of shares held by the board membership is included in the model and is used to control the directors' monitoring incentives. Agency theory suggests that board ownership (PBDown) encourages directors to protect their equity in the firm. It follows that a board with higher ownership will engage in more extensive monitoring and thus enhance a firm's performance. Previous research finds that board ownership positively relates to Tobin's $Q,{ }^{14}$ and profitability. ${ }^{36}$ Therefore, we expect board ownership to be positively related to a firm's efficiency. Board compensation could also affect a firm's performance. Higher board compensation could induce the directors to conduct their duties more efficiently in order to keep their positions, and thus increase the efficiency of a firm. On the other hand, Core et al. ${ }^{37}$ suggest, to the contrary, that a firm compensating its directors more may have greater agency cost and exhibits poor performance. Therefore, we hypothesise that there is no relation between board compensation and a firm's efficiency performance. Note that none of our sampled insurers rewarded their board members with the non-cash compensation. Therefore, we define board compensation (ComB) as the total cash compensation of

\footnotetext{
34 Wang et al. (2007).

35 Bacon and Brown (1975).

${ }^{36}$ Lin et al. (2008).

${ }^{37}$ Core et al. (1999).
} 
Table 2 Corporate governance variable definitions

\begin{tabular}{|c|c|c|}
\hline Variables & Predicted sign & Definition \\
\hline \multicolumn{3}{|c|}{ Dependent variable } \\
\hline EFS & & $\begin{array}{l}\text { Efficiency scores for technical efficiency, allocative } \\
\text { efficiency, cost efficiency, and revenue efficiency }\end{array}$ \\
\hline \multicolumn{3}{|c|}{ Independent variables } \\
\hline $\ln B D s i z e$ & $?$ & Natural logarithm of the number of directors on the board \\
\hline dBDind & $?$ & $\begin{array}{l}\text { One if the board is dominated ( } 50 \text { per cent or more) by } \\
\text { independent directors, and zero otherwise }\end{array}$ \\
\hline $\operatorname{lnBDmeet}$ & $?$ & Natural logarithm of the number of board meetings \\
\hline $\ln A D s i z e$ & $?$ & $\begin{array}{l}\text { Natural logarithm of the number of audit committee } \\
\text { members }\end{array}$ \\
\hline $\ln \mathrm{ADm} e e t$ & $?$ & $\begin{array}{l}\text { Natural logarithm of the number of audit committee } \\
\text { meetings }\end{array}$ \\
\hline PADexpert & $?$ & Proportion of financial experts on audit committee \\
\hline Divergence & - & The difference between voting rights and cash flow rights \\
\hline $\ln$ Tenure & $?$ & $\begin{array}{l}\text { Natural logarithm of the average number of years the } \\
\text { directors has been on the board }\end{array}$ \\
\hline lnBDage & $?$ & $\begin{array}{l}\text { Natural logarithm of the average age of directors on the } \\
\text { board }\end{array}$ \\
\hline PBDown & + & Proportion of shares held by board members \\
\hline ComB & $?$ & $\begin{array}{l}\text { Total cash compensation of directors on the board divided } \\
\text { by total assets }\end{array}$ \\
\hline $\ln$ Size & $?$ & Natural logarithm of total assets divided by 1 million \\
\hline
\end{tabular}

its directors on the board, divided by total assets. Finally, a firm's size (lnSize) is included in the model, to control the size effect on efficiency. Firm size is defined as the natural logarithm of total assets divided by 1 million. Studies find that firm size positively relates to Tobin's $Q,{ }^{8,14}$ and profitability. ${ }^{36}$ However, to the contrary, Cummins et al..$^{38}$ and Hardwick et al. ${ }^{17}$ point out that the larger insurers may experience decreasing returns to scale. Therefore, we hypothesise that there is no relation between a firm's size and its efficiency performance. The definitions and predicted signs of corporate governance variables are summarised in Table 2 .

\section{Methodology}

To test our hypotheses, we first calculate the efficiency scores on technical, allocative, cost, and revenue efficiency via DEA methodology in the DEAP and DEA SOLVER programmes. Cost efficiency is the product of technical efficiency and allocative efficiency. Technical efficiency measures the ability of each firm's use of optimal proportions, in a given set of inputs, to obtain the maximal outputs. Allocative efficiency measures the ability of each firm's use of its inputs, in optimal proportions, from the given input prices. Revenue efficiency measures the ability of each firm's use

\footnotetext{
${ }^{38}$ Cummins et al. (1998).
} 
of optimal outputs to obtain the maximal revenue. All four efficiency scores vary between zero and one, and full efficiency is a score of one.

We next use the efficiency scores as dependent variables and examine the relation between the efficiency scores and corporate governance. Because the values of these efficiency scores are generated from a DEA procedure, they could suffer from serial correlation such that the estimates will be inconsistent and biased. Efron and Tibshirani $^{39}$ and Simar and Wilson ${ }^{40}$ propose to use a bootstrap procedure to overcome this problem and improve statistical efficiency. We therefore employ a STATA programme and conduct truncated bootstrapped regression models in the second stage. The regression is specified as follows. Significantly positive (negative) coefficient estimates for corporate governance variables suggest that a board with certain characteristics increases (decreases) efficiency.

$$
\begin{aligned}
\text { EFS }_{i t}= & \alpha+\beta_{1} \ln \text { BDsize }_{i t}+\beta_{2} \text { dBDind }_{i t}+\beta_{3} \ln \text { BDmeet }_{i t} \\
& +\beta_{4} \ln \text { ADsize }_{i t}+\beta_{5} \ln \text { ADmeet }_{i t}+\beta_{6} \text { PADexpert }_{i t} \\
& +\beta_{7} \text { Divergence }_{i t}+\beta_{8} \ln \text { Tenure }_{i t}+\beta_{9} \ln \text { BDage }_{i t} \\
& +\beta_{10} \text { PBDown }_{i t}+\beta_{11} \text { ComB }_{i t}+\beta_{12} \ln \text { Size }_{i t}+\beta_{13} \text { Year }_{t}+\varepsilon_{i t}
\end{aligned}
$$

where $i=$ company index, $t=$ year index, and EFS includes technical, allocative, cost, and revenue efficiency scores.

\section{Empirical results}

In this section we first present the summary statistics on DEA variables and then discuss the results of the efficiency analysis. We then show the regression results for technical, allocative, cost, and revenue efficiency.

\section{Summary statistics}

We report Pearson Correlations among DEA variables in Table 3. The averages of input quantities, input prices, and expenses of the non-life insurance industry from periods 2000 to 2007 are reported in Table 4 . The average quantity and price of administrative and agent labours (equity capital, and material and business services) are 1,638 persons (1,788, and 827 million baht), and 0.25 million baht (3.79, and 2.46 per cent), respectively. The average expenses of administrative and agent labours (equity capital, and material and business services) is 348.42 million baht $(68.87$, and 21.85 million baht).

Table 5 presents the averages of output quantities, output prices, and revenues. The average quantity and price of losses incurred (intermediation) are 623 million baht (2,619 million baht), and 1.30 (5.23 per cent), respectively. The average revenue of losses incurred (intermediation) is 548.96 million baht (162.78 million baht).

\footnotetext{
39 Efron and Tibshirani (1993).

40 Simar and Wilson (2007).
} 


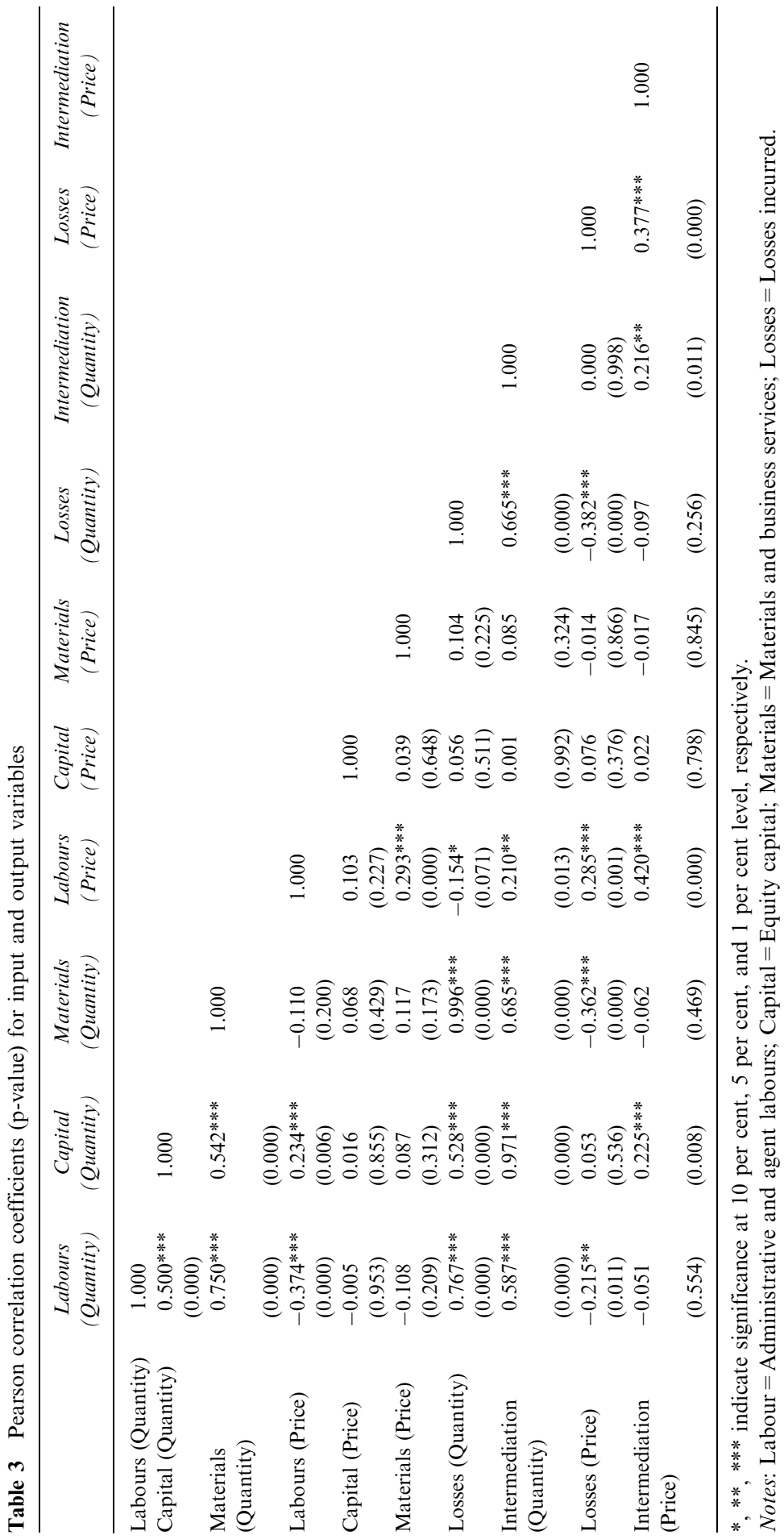


Table 4 Inputs and expenses

\begin{tabular}{|c|c|c|c|c|c|c|c|c|c|}
\hline & 2000 & 2001 & 2002 & 2003 & 2004 & 2005 & 2006 & 2007 & Average \\
\hline \multicolumn{10}{|l|}{ Input quantities } \\
\hline Administrative and agent labours (Person) & 1,583 & 1,928 & 1,777 & 2,097 & 1,235 & 1,341 & 1,401 & 1,722 & 1,638 \\
\hline Equity capital (million baht) & 1,230 & 1,332 & 1,447 & 1,962 & 1,896 & 2,027 & 2,165 & 2,357 & 1,788 \\
\hline Materials and business services (million baht) & 597 & 629 & 701 & 777 & 872 & 928 & 1,009 & 1,152 & 827 \\
\hline \multicolumn{10}{|l|}{ Input prices } \\
\hline Administrative and agent labours (million baht) & 0.21 & 0.20 & 0.22 & 0.22 & 0.28 & 0.29 & 0.30 & 0.31 & 0.25 \\
\hline Equity capital (per cent) & 4.66 & 4.02 & 2.94 & 2.20 & 1.85 & 3.15 & 5.43 & 6.17 & 3.79 \\
\hline Materials and business services (per cent) & 1.59 & 1.63 & 0.70 & 1.80 & 2.76 & 4.54 & 4.64 & 2.24 & 2.46 \\
\hline \multicolumn{10}{|l|}{ Expenses (million baht) } \\
\hline Administrative and agent labours & 262.92 & 314.78 & 322.54 & 395.37 & 306.26 & 350.67 & 379.04 & 471.3 & 348.42 \\
\hline Equity capital $^{\mathrm{a}}$ & 57.29 & 53.60 & 42.56 & 43.17 & 35.03 & 63.90 & 117.53 & 145.52 & 68.87 \\
\hline Materials and business services & 9.51 & 10.23 & 4.89 & 14.01 & 24.06 & 42.15 & 46.78 & 25.83 & 21.85 \\
\hline
\end{tabular}

${ }^{a}$ Equity capital expense is the product of capital input and the price of capital.

Table 5 Outputs and revenues

\begin{tabular}{|c|c|c|c|c|c|c|c|c|c|}
\hline & 2000 & 2001 & 2002 & 2003 & 2004 & 2005 & 2006 & 2007 & Average \\
\hline \multicolumn{10}{|c|}{ Output quantities (million baht) } \\
\hline Losses incurred & 448 & 479 & 532 & 589 & 667 & 693 & 752 & 860 & 623 \\
\hline Intermediation & 1,847 & 1,989 & 2,203 & 2,936 & 2,809 & 964 & 3,010 & 3,348 & 2,619 \\
\hline \multicolumn{10}{|l|}{ Output prices } \\
\hline Losses incurred (unit) & 1.83 & 1.47 & 1.15 & 1.15 & 1.12 & 1.34 & 1.22 & 1.11 & 1.30 \\
\hline Intermediation (per cent) & 5.41 & 5.71 & 4.95 & 4.87 & 5.28 & 5.35 & 4.70 & 5.57 & 5.23 \\
\hline \multicolumn{10}{|l|}{ Revenues (million baht) } \\
\hline Losses incurred & 464.40 & 489.84 & 449.77 & 480.49 & 550.03 & 638.57 & 647.02 & 694.43 & 548.96 \\
\hline Intermediation & 118.44 & 139.25 & 136.89 & 199.69 & 171.02 & 176.21 & 168.28 & 200.17 & 162.78 \\
\hline
\end{tabular}

Table 6 presents the summary statistics of efficiency scores, the corporate governance variables, and other control variables. On average, the technical efficiency score is 94.1 per cent, suggesting that firms could have produced the same outputs by using 94.1 per cent of the inputs. This result is much higher than that found in Cummins and Nini ${ }^{8}$ (57.6 per cent), which used U.S.A.'s non-life insurer samples, but closer to Wang et al. ${ }^{34}$ (93.9 per cent), which used Taiwan's non-life insurer samples. The allocative efficiency score is on average 62.6 per cent, suggesting that firms could have produced the same outputs by using 62.6 per cent of the inputs, if inputs were optimally allocated. This result is lower than Cummins and $\mathrm{Nini}^{8}$ (79.8 per cent) and Wang et al..$^{34}$ (75.7 per cent). The average cost efficiency score is approximately 59.3 per cent, which is higher than Cummins and $\mathrm{Nini}^{8}$ (40.6 per cent), but lower than Wang et al. ${ }^{34}$ (71.9 per cent). Finally, the revenue efficiency score is on average 85.2 per cent, suggesting that these firms could have increased revenue by 14.8 per cent when obtaining optimal outputs. 
Table 6 Descriptive statistics

\begin{tabular}{|c|c|c|c|c|c|}
\hline Variables & Mean & Median & Std Dev & Minimum & Maximum \\
\hline Technical efficiency & 0.941 & 0.988 & 0.089 & 0.617 & 1.000 \\
\hline Allocative efficiency & 0.626 & 0.615 & 0.231 & 0.122 & 1.000 \\
\hline Cost efficiency & 0.593 & 0.575 & 0.238 & 0.092 & 1.000 \\
\hline Revenue efficiency & 0.852 & 0.885 & 0.126 & 0.498 & 1.000 \\
\hline $\ln B D$ size & 2.513 & 2.485 & 0.171 & 2.079 & 2.944 \\
\hline dBDind & 0.051 & 0.000 & 0.220 & 0.000 & 1.000 \\
\hline $\ln B D m e e t$ & 1.826 & 1.792 & 0.394 & 1.386 & 2.833 \\
\hline $\ln A D$ size & 1.140 & 1.099 & 0.102 & 1.099 & 1.386 \\
\hline $\ln \mathrm{ADm}$ met & 1.641 & 1.386 & 0.369 & 1.386 & 2.639 \\
\hline PADexpert & 0.395 & 0.333 & 0.197 & 0.250 & 1.000 \\
\hline Divergence & 0.215 & 0.182 & 0.154 & -0.123 & 0.644 \\
\hline lnTenure & 2.114 & 2.152 & 0.460 & 0.406 & 2.976 \\
\hline lnBDage & 4.077 & 4.078 & 0.072 & 3.884 & 4.245 \\
\hline PBDown & 0.109 & 0.057 & 0.132 & 0.000 & 0.588 \\
\hline ComB & 0.002 & 0.001 & 0.001 & 0.000 & 0.008 \\
\hline $\operatorname{lnSize}$ & 7.658 & 7.568 & 0.972 & 5.899 & 9.876 \\
\hline
\end{tabular}

Notes: The sample includes 138 firm years from 2000 to 2007. Corporate governance data and financial information are obtained from Annual Registration Statement in Thailand. $\ln$ BDsize $=$ natural logarithm of the number of directors on the board; $\mathrm{dBDind}=$ one if the board is dominated ( 50 per cent or more) by independent directors, and zero otherwise; $\operatorname{lnBDmeet}=$ natural logarithm of the number of board meetings; $\ln \mathrm{AD}$ size $=$ natural logarithm of the number of audit committee members; $\ln$ ADmeet $=$ natural logarithm of the number of audit committee meetings; PADexpert = proportion of financial experts on audit committee; Divergence $=$ the difference between voting rights and cash flow rights; lnTenure $=$ natural logarithm of the average number of years the directors has been on the board; lnBDage = natural logarithm of the average age of directors on the board; PBDown= proportion of shares held by board members; ComB $=$ total cash compensation of directors on the board divided by total assets; lnSize = natural logarithm of total assets divided by 1 million.

The average board size is 12.3 members, which is much higher than that required by the Public Limited Company Act (five members) and OIC (seven members) in Thailand. In our sample, 5.1 per cent of the board is dominated by independent directors. The board meeting frequency ranges from 4 to 17 times per year and its average is 6.2 times per year. With regard to audit committee variables, the size of the audit committee is approximately 3.1 members, with 39.5 per cent of its members possessing financial or accounting expertise. The meeting frequency of the audit committee ranges from 4 to 14 times per year and averages 5.2 times per year. In addition, the average divergence between voting rights and cash flow rights is 0.215 , the average board tenure is 9.122 years, and the average age of the directors is 59 years of age. The average ownership of board members is 10.9 per cent. The board of directors receives 0.2 per cent of total assets as compensation. Finally, the average firm size is 7.658.

\section{The regression results}

Table 7 reports the regression results estimated by the truncated bootstrapped regression model. The dependent variables consist of four efficiency scores and the independent variables consist of corporate governance variables, control variables, 
Table 7 Truncated bootstrapped regression models with efficiency scores as dependent variable

\begin{tabular}{|c|c|c|c|c|}
\hline & Technical efficiency & Allocative efficiency & Cost efficiency & Revenue efficiency \\
\hline \multirow{2}{*}{ Constant } & $2.782 * * *$ & $3.013 * * *$ & $3.942 * * *$ & $3.565^{* * *}$ \\
\hline & $(0.624)$ & $(0.902)$ & $(0.754)$ & $(0.721)$ \\
\hline \multirow[t]{2}{*}{$\ln B D s i z e$} & $0.073 * *$ & $0.155^{*}$ & $0.222 * *$ & $-0.146 * * *$ \\
\hline & $(0.036)$ & $(0.092)$ & $(0.095)$ & $(0.051)$ \\
\hline \multirow{2}{*}{ dBDind } & 0.037 & $0.078 *$ & $0.099 *$ & $0.129 * * *$ \\
\hline & $(0.045)$ & $(0.047)$ & $(0.056)$ & $(0.037)$ \\
\hline \multirow[t]{2}{*}{ lnBDmeet } & -0.029 & $0.089 * *$ & $0.067^{*}$ & 0.004 \\
\hline & $(0.023)$ & $(0.043)$ & $(0.036)$ & $(0.024)$ \\
\hline \multirow[t]{2}{*}{$\ln A D s i z e$} & $-0.412 * * *$ & 0.017 & $-0.304 *$ & $-0.658 * * *$ \\
\hline & $(0.087)$ & $(0.138)$ & $(0.169)$ & $(0.093)$ \\
\hline \multirow[t]{2}{*}{ lnADmeet } & $-0.084 * * *$ & -0.046 & $-0.097 * *$ & -0.012 \\
\hline & $(0.015)$ & $(0.050)$ & $(0.044)$ & (0.019) \\
\hline \multirow[t]{2}{*}{ PADexpert } & $-0.115^{* * *}$ & $0.312 * * *$ & $0.219 * *$ & $-0.071^{* *}$ \\
\hline & $(0.033)$ & $(0.115)$ & $(0.097)$ & $(0.033)$ \\
\hline \multirow[t]{2}{*}{ Divergence } & $-0.159 * * *$ & $-0.429 * * *$ & $-0.517 * * *$ & $-0.249 * * *$ \\
\hline & $(0.052)$ & $(0.151)$ & $(0.158)$ & $(0.041)$ \\
\hline \multirow[t]{2}{*}{$\ln$ Tenure } & $-0.050 * * *$ & $-0.090 * *$ & $-0.118 * * *$ & 0.009 \\
\hline & $(0.018)$ & $(0.041)$ & $(0.042)$ & $(0.021)$ \\
\hline \multirow[t]{2}{*}{ lnBDage } & $-0.404 * * *$ & $-0.693 * * *$ & $-0.901 * * *$ & $-0.473 * * *$ \\
\hline & $(0.131)$ & $(0.196)$ & $(0.197)$ & $(0.162)$ \\
\hline \multirow[t]{2}{*}{ PBDown } & $-0.067^{*}$ & 0.016 & -0.034 & $-0.245 * * *$ \\
\hline & $(0.036)$ & $(0.192)$ & $(0.158)$ & $(0.082)$ \\
\hline \multirow[t]{2}{*}{ ComB } & $22.061 * * *$ & $-27.162^{* *}$ & -9.723 & -10.386 \\
\hline & (5.987) & (12.389) & $(15.185)$ & (8.716) \\
\hline \multirow[t]{2}{*}{$\operatorname{lnSize}$} & $0.060 * * *$ & $0.039 *$ & $0.078 * * *$ & $0.054 * * *$ \\
\hline & $(0.009)$ & $(0.022)$ & $(0.027)$ & $(0.011)$ \\
\hline Log likelihood & 187.125 & 74.504 & 72.063 & 154.177 \\
\hline $\begin{array}{l}\text { Total number of } \\
\text { bootstrapped iterations }\end{array}$ & 1500 & 1500 & 1500 & 1500 \\
\hline
\end{tabular}

The coefficients of year dummy variables are omitted. Bootstrap standard errors are presented in parentheses.

*, **, *** indicate significance at 10 per cent, 5 per cent, and 1 per cent level, respectively.

Notes: 1. The sample includes 138 firm years from 2000 to 2007. Corporate governance data and financial information are obtained from Annual Registration Statement in Thailand. 2. $\ln$ BDsize = natural logarithm of the number of directors on the board; $\mathrm{dBDind}=$ one if the board is dominated ( 50 per cent or more) by independent directors, and zero otherwise; $\operatorname{lnBDmeet}=$ natural logarithm of the number of board meetings; $\ln A D s i z e=$ natural logarithm of the number of audit committee members; $\operatorname{lnADmeet}=$ natural logarithm of the number of audit committee meetings; PADexpert = proportion of financial experts on audit committee; Divergence $=$ the difference between voting rights and cash flow rights; $\ln$ Tenure $=$ natural logarithm of the average number of years the directors has been on the board; lnBDage = natural logarithm of the average age of directors on the board; $\mathrm{PBDown}=$ proportion of shares held by board members; $\mathrm{ComB}=$ total cash compensation of directors on the board divided by total assets; $\ln$ Size $=$ natural logarithm of total assets divided by 1 million.

and year dummy variables. To save space, the coefficients of year dummy variables are omitted. We tested for correlation among the independent variables and the results of variance inflation factors revealed that there are no problems with multicollinearity.

Consistent with Hardwick et al. ${ }^{17}$ and Huang et al., ${ }^{20}$ board size is positively and significantly correlated with technical, allocative, and cost efficiency, suggesting that 
more knowledge backgrounds and more varied opinions provided by a larger board increase a firm's efficiency. However, board size is negatively and significantly correlated with revenue efficiency, indicating that a small number of directors on the board enables firms to obtain better efficiency performance via reducing coordination problems that exist in large boards. ${ }^{12}$ Regarding the relation between board independence and the efficiency performance of insurers, the results show that board independence is positively related to allocative and cost efficiency, and are consistent with Wang et $a l .{ }^{33}$ In addition, we also find that board independence is positively related to revenue efficiency. Collectively, the results suggest that a board dominated by independent directors is associated with effective monitoring that enhances a firm's efficiency.

Consistent with Huang et al., ${ }^{10}$ board meeting frequency is positively correlated to its allocative and cost efficiency. The result indicates that board diligence can improve the efficiency performance of a firm because the board has more opportunities to monitor management performance.

With respect to the audit committee characteristics, the committee size is negatively related to technical, cost, as well as revenue efficiency, suggesting that increasing committee size decreases a firm's efficiency. In the same direction, we also find that audit committee meeting frequency is negatively related to technical and cost efficiency. The results suggest that the effectiveness of an audit committee decreases with overloaded agendas and activities on compliance. The proportion of financial expertise on an audit committee is positively associated with allocative and cost efficiency, indicating that the more financial experts on an audit committee help the board in preventing financial reporting and irregularity problems. However, on the contrary, financial expertise on an audit committee is negatively associated with technical and revenue efficiency. This result is consistent with Huang et al. ${ }^{10}$ that more financial experts on an audit committee would be harmful to a firm's efficiency performance, provided they do not have sufficient experience, which would lead to ineffective monitoring.

Apart from the above results, divergence is negatively related to a firm's efficiency performance, suggesting that increasing divergence between voting rights and cash flow rights decreases a firm's efficiency. ${ }^{34,41,42}$ On the contrary, we find a negative relation between a board's tenure and technical, allocative, and cost efficiency, suggesting that longer board tenure harms the efficiency performance of a firm, because the familiarity between board members and managers may prevent them from effectively monitoring said managers. We also find a negative relation between board age and efficiency, indicating that increasing the average age of the directors on the board would be harmful to the efficiency performance of a firm, because senior directors may respond to their duties slower than younger directors, conceivably due to poor health problems or higher age.

Board ownership is negatively related to technical and revenue efficiency, implying that increasing board ownership would harm the efficiency of a firm. Board compensation is significantly and positively related to technical efficiency. This result indicates that higher board compensation could induce directors to do their duty more

\footnotetext{
${ }^{41}$ Claessens et al. (2000).

${ }^{42}$ Faccio and Lang (2002).
} 
efficiently, in order to keep their positions and thus, to increase the efficiency of a firm. However, board compensation is significantly and negatively related to allocative efficiency. The result confirms Core et al. ${ }^{37}$ which state that firms compensating their directors more will have higher agency costs, and thus, exhibit poor performance. Finally, consistent with prior literature, ${ }^{5,9,14,36}$ firm size is positively and statistically significant to all the efficiency measures of a firm.

\section{Conclusions}

The purpose of this paper is to investigate the relationship between various aspects of corporate governance characteristics and the efficiency performance of the non-life insurance companies in Thailand. We use public Thai non-life insurance companies from the years 2000 to 2007 as samples. To examine our hypotheses, we first employ the DEA to calculate the efficiency scores and then use truncated bootstrapped regression to test the relationship between efficiency scores and corporate governance variables.

Our paper adds to the literature in three aspects. First, this paper is the first of its kind to investigate the impact of corporate governance on the efficiency performance of Thai non-life insurance companies, given that the Thai government has enacted so many regulations for corporate governance after the Asian Financial Crisis. Second, we investigate the impact of a more complete set of board/audit committee characteristics on the insurer's efficiency performance. Third, unlike prior literature, we also investigate the relation between revenue efficiency and corporate governance, allowing us to examine whether good corporate governance is rewarded by the market.

The empirical results reveal that the characteristics of corporate governance do influence the efficiency performance of non-life insurers. Specifically, board independence is positively correlated with allocative, cost, and revenue efficiency, suggesting that board independence enhances a firm's efficiency. Moreover, we find evidence that board meeting frequency is positively correlated to allocative and cost efficiency. The result indicates that board diligence can improve the efficiency performance of firm because the board has more opportunities to monitor the performance of management.

For audit committee characteristics, the results show that an audit committee size is negatively related to technical, cost, as well as revenue efficiency, suggesting that increasing committee size decreases a firm's efficiency. In the same direction, we also find that audit committee meeting frequency is negatively related to technical and cost efficiency. The results suggest that the effectiveness of an audit committee decreases with overloaded agendas and activities on compliance, lowering a firm's efficiency. Finally, divergence between voting rights and cash flow rights also has a negative impact on efficiency.

Our empirical results may encourage more studies to examine further the links between any other aspects of corporate governance characteristics and performance of the Thai insurance industry. Although this study uses only the data from the public Thai non-life insurance companies, its findings could have further implications for regulators in Thailand to set up corporate governance requirements. Specifically, our results show that a board dominated by independent directors significantly improves 
its efficiency, while the proportion of independent directors generates mixed results, suggesting that the requirement for a minimum proportion of independent directors to be on a board may not enhance a firm's performance, due to majority rule. Instead, a board dominated by its independent directors contributes to a firm's performance. Another implication derived from our results is that the characteristics that make up an audit committee may generate negative results. As mentioned earlier, a possible explanation is the requirement by the Thai government that audit committee members cannot hold more than five per cent shares of the firm. This is in contrast with the findings by Klein ${ }^{24}$ and Ahmed and Duellman ${ }^{43}$ which state that stock ownership increases monitoring incentives, and such a requirement decreases this monitoring incentive, undermining the effectiveness of an audit committee.

\section{References}

Abbott, L.J., Peters, G.F. and Raghunandan, K. (2003) 'The association between audit committee characteristics and audit fees', Auditing: A Journal of Practice \& Theory 22(2): 1-15.

Agrawal, A. and Chadha, S. (2005) 'Corporate governance and accounting scandals', Journal of Law and Economics 48(2): 371-406.

Agrawal, A. and Knoeber, C.R. (1996) 'Firm performance and mechanisms to control agency problems between managers and shareholders', Journal of Financial and Quantitative Analysis 31: 377-397.

Ahmed, A.S. and Duellman, S. (2007) 'Accounting conservatism and board of director characteristics: An empirical analysis', Journal of Accounting and Economics 43(2-3): 411-437.

Anderson, R.C., Mansi, S.A. and Reeb, D.M. (2004) 'Board characteristics, accounting report integrity, and the cost of debt', Journal of Accounting and Economics 37(3): 315-342.

Bacon, J. and Brown, J.K. (1975) Corporate Directorship Practices: Role, Selection and Legal Status of the Board, New York: Conference Board.

Beasley, M.S. (1996) 'An empirical analysis of the relation between the board of director composition and financial statement fraud', The Accounting Review 71(4): 443-465.

Claessens, S., Djankov, S. and Lang, L. (2000) 'The separation of ownership and control in East Asian Corporations', Journal of Financial Economics 58(1-2): 81-112.

Claessens, S., Djankov, S., Fan, J. and Lang, L. (2002) 'Disentangling the incentive and entrenchment effects of large shareholdings', The Journal of Finance 57(6): 2741-2771.

Connelly, J.T. and Limpaphayom, P. (2004) 'Board characteristics and firm performance: Evidence from the life insurance industry in Thailand', Chulalongkorn Journal of Economics 16(2): 101-124.

Conyon, M.J. and Peck, S.I. (1998) 'Board size and corporate performance: Evidence from European countries', The European Journal of Finance 4(3): 291-304.

Core, J.E., Holthausen, R.W. and Larcker, D.F. (1999) 'Corporate governance, chief executive officer compensation, and firm performance', Journal of Financial Economics 51(3): 371-406.

Cummins, J.D. and Nini, G.P. (2002) 'Optimal capital utilization by financial firms: Evidence from the property-liability insurance industry', Journal of Financial Services Research 21(1): 15-53.

Cummins, J.D. and Weiss, M.A. (2000) 'Analyzing firm performance in the insurance industry using frontier efficiency and productivity method', in G. Dionne (ed.) Handbook of Insurance, Boston, MA: Kluwer Academic Publishers, pp. 767-829.

Cummins, J.D., Tennyson, S. and Weiss, M.A. (1998) 'Consolidation and efficiency in the U.S. life insurance industry', Journal of Banking and Finance 23(2-4): 325-357.

Dalton, D.R., Daily, C.M., Johnson, J.L. and Ellstrand, A.E. (1999) 'Number of directors and financial performance: A meta-analysis', Academy of Management Journal 42(6): 674-686.

Dowen, R.J. (1995) 'Board of director quality and firm performance', International Journal of the Economics of Business 2(1): 123-132.

${ }^{43}$ Ahmed and Duellman (2007). 
S48

Efron, B. and Tibshirani, R.J. (1993) An Introduction to Bootstrap, London: Chapman \& Hall.

Evans, J., Evans, R. and Loh, S. (2002) 'Corporate governance and declining firm performance', International Journal of Business Studies 10(1): 1-18.

Faccio, M. and Lang, L. (2002) 'The ultimate ownership of Western European corporations', Journal of Financial Economics 65(3): 365-395.

Fama, E.F. and Jensen, M.C. (1983) 'Separation of ownership and control', Journal of Law and Economics 26(2): 301-325.

Hardwick, P., Adams, M. and Zou, H. (2004) Corporate Governance and Cost Efficiency in the United Kingdom Life Insurance Industry, Working paper.

Herold, D.E. (1979) 'The effectiveness of work groups', in S Kerr (ed.) Organizational Behavior, Columbus, OH: Grid Publishing, pp. 95-118.

Huang, L.Y., Lai, G.C. and Wang, J.L. (2008a) The effects of corporate governance and auditor independence on the efficiency performance of the U.S. property liability insurance industry, paper presented at Asia-Pacific Risk and Insurance Association, $12^{\text {th }}$ Annual Conference, Sydney, Australia.

Huang, L.Y., Lai, G.C. and Wen, M.M. (2008b) The effects of corporate governance and auditor independence on the efficiency performance of the U.S. life insurance industry, paper presented at Asia-Pacific Risk and Insurance Association, $12^{\text {th }}$ Annual Conference, Sydney, Australia.

Jensen, M.C. (1993) 'The modern industrial revolution, exit, and the failure of internal control systems', The Journal of Finance 48(3): 831-880.

Johnson, S., Boone, P., Breach, A. and Friedman, E. (2000) 'Corporate governance in the Asian financial crisis', Journal of Financial Economics 58(1-2): 141-186.

Kajola, S.O. (2008) 'Corporate governance and firm performance: The case of Nigerian listed firms', European Journal of Economics, Finance and Administrative Sciences 14: 16-28.

Kalbers, L.P. and Fogarty, T.J. (1993) 'Audit committee effectiveness: An empirical investigation of the contribution of power', Auditing: A Journal of Practice and Theory 12(1): 24-49.

Klein, A. (2002) 'Audit committee, board of director characteristics, and earnings management', Journal of Accounting and Economics 33(3): 375-400.

KPMG (2008) 'Audit Committees Put Risk Management at the Top of Their Agendas', from www.kpmg.co.uk/news/detail.cfm?pr $=3120$, accessed 15 December 2009.

Leightner, J.E. (2007) 'Thailand's financial crisis: Its causes, consequences, and implications', Journal of Economic Issue 41: 61-74.

Lin, Y-C., Huang, S.Y. and Young, S-C. (2008) 'An empirical study on the relationship between ownership and firm performance: Taiwan evidence', Afro-Asian Journal of Financial and Accounting 1(1): $67-80$.

Menon, K. and Deahl Williams, J. (1994) 'The use of audit committees for monitoring', Journal of Accounting and Public Policy 13(2): 121-139.

Nikomborirak, D. and Tangkitvanich, S. (1999) Corporate governance: The challenge facing the Thai economy, paper presented at the conference on Corporate Governance in Asia: A Comparative Perspective, Seoul, Korea.

Pathan, S., Skully, M.T. and Wickramanayake, J. (2007) 'Board size, independence and performance: An analysis of Thai banks', Asia-Pacific Financial Markets 14(3): 211-227.

Rebeiz, K.S. and Salameh, Z. (2006) 'Relationship between governance structure and financial performance in construction', Journal of Management in Engineering 22(1): 20-26.

Simar, L. and Wilson, P.W. (2007) 'Estimation and inference in two-stage, semi-parametric models of production processes', Journal of Econometrics 136(1): 31-64.

Vafeas, N. (1999) 'Board meeting frequency and firm performance', Journal of Financial Economics 53(1): $113-142$.

Viverito, J. (1998) 'Corporate governance in the Kingdom of Thailand', Malaysian Journal of Economic Studies 35(1-2): 231-245.

Wang, J.L., Jeng, V. and Peng, J.L. (2007) 'The impact of corporate governance structure on the efficiency performance of insurance companies in Taiwan', The Geneva Papers on Risk and InsuranceIssues and Practice 32(2): 264-282.

Yermack, D. (1996) 'Higher market valuation of companies with a small board of directors', Journal of Financial Economics 40(2): 185-211. 


\section{About the Authors}

Wen-Yen Hsu is an Associate Professor in the Department of Risk Management and Insurance at Feng Chia University in Taiwan.

Pongpitch Petchsakulwong is a lecturer in the risk management and insurance area at the Faculty of Commerce and Management, Prince of Songkla University, Thailand. $\mathrm{He}$ is leaving to pursue his $\mathrm{PhD}$ at Feng Chia University, Taiwan. 